Research article

Open Access

\title{
Dendritic cells loaded with killed breast cancer cells induce differentiation of tumor-specific cytotoxic T lymphocytes
}

\author{
Eve-Marie Neidhardt-Berard ${ }^{1}$, Frederic Berard ${ }^{2}$, Jacques Banchereau ${ }^{3}$ and A Karolina Palucka ${ }^{3}$
}

\author{
${ }^{1}$ Centre Léon-Bérard, Laboratoire de thérapie cellulaire et greffes hématopoiètiques, Lyon, France \\ 2Unité d'Immunologie Clinique et Allergologie, CHU Lyon-Sud, France \\ ${ }^{3}$ Baylor Institute for Immunology Research, Dallas, Texas, USA \\ Corresponding author: A Karolina Palucka, karolinp@baylorhealth.edu
}

Received: 29 Jul 2003 Revisions requested: 30 Sep 2003 Revisions received: 25 Feb 2004 Accepted: 25 Mar 2004 Published: 30 Apr 2004

Breast Cancer Res 2004, 6:R322-R328 (DOI 10.1186/bcr794)

(C) 2004 Neidhardt-Berard et al.; licensee BioMed Central Ltd. This is an Open Access article: verbatim copying and redistribution of this article are permitted in all media for any purpose, provided this notice is preserved along with the article's original URL.

\begin{abstract}
Background Early clinical trials, mostly in the setting of melanoma, have shown that dendritic cells (DCs) expressing tumor antigens induce some immune responses and some clinical responses. A major difficulty is the extension to other tumors, such as breast carcinoma, for which few defined tumorassociated antigens are available. We have demonstrated, using both prostate carcinoma and melanoma as model systems, that DCs loaded with killed allogeneic tumor cell lines can induce $\mathrm{CD}^{+} \mathrm{T}$ cells to differentiate into cytotoxic $\mathrm{T}$ lymphocytes (CTLs) specific for shared tumor antigens.
\end{abstract}

Methods The present study was designed to determine whether DCs would capture killed breast cancer cells and present their antigens to autologous $\mathrm{CD}^{+}$and $\mathrm{CD} 8^{+} \mathrm{T}$ cells.
Results We show that killed breast cancer cells are captured by immature DCs that, after induced maturation, can efficiently present $\mathrm{MHC}$ class I and class II peptides to $\mathrm{CD}^{+}$and $\mathrm{CD} 4^{+} \mathrm{T}$ lymphocytes. The elicited CTLs are able to kill the target cells without a need for pretreatment with interferon gamma. CTLs can be obtained by culturing the DCs loaded with killed breast cancer cells with unseparated peripheral blood lymphocytes, indicating that the DCs can overcome any potential inhibitory effects of breast cancer cells.

Conclusion Loading DCs with killed breast cancer cells may be considered a novel approach to breast cancer immunotherapy and to identification of shared breast cancer antigens.

Keywords: breast cancer, cell death, dendritic cells, immunotherapy, tumor immunity

\section{Introduction}

The concept of cancer immunotherapy has been energized in the past decade by the molecular identification of human cancer antigens [1-6]. These therapeutic approaches were further facilitated through identification of in vitro culture methods, allowing generation of large numbers of dendritic cells (DCs) [7-9] on which the cancer antigens can be presented to $T$ cells [10-15]. Numerous studies in animals have demonstrated that immunization with tumor antigenloaded DCs induces protective antitumor responses [1619]. However, optimal antigen loading strategies for human trials still remain to be determined.

The most commonly used, clinical grade approach is based on loading empty MHC class I molecules with exogenous peptides. This approach is limited, however, by peptide restriction to a given human leukocyte antigen (HLA) type, by induction of cytotoxic $\mathrm{T}$ lymphocyte (CTL) responses only, and by limitation of the induced responses to defined tumor-associated antigens.

We have demonstrated that DCs loaded with killed allogeneic tumor cell lines can induce $C D 8^{+} \mathrm{T}$ cells to differentiate into shared tumor antigen-specific effectors, using both prostate carcinoma and melanoma as model systems $[20,21]$. Such an approach offers new possibilities for tumor-associated antigen delivery to DCs because the use of tumor cells as a source of antigens should provide both MHC class I and class II epitopes, leading to a diverse immune response involving many clones of CTLs and

ATCC = American Type Culture Collection; cpm = counts per minute; CTL = cytotoxic T lymphocyte; DC = dendritic cell; ELISA = enzyme-linked immunosorbent assay; FCS = fetal calf serum; FITC = fluorescein isothiocyanate; HLA = human leukocyte antigen; IL = interleukin; IFN- $\gamma=$ interferon gamma; $\mathrm{mAb}=$ monoclonal antibody; $\mathrm{MHC}=$ major histocompatibility complex; $\mathrm{PBL}=$ peripheral blood lymphocytes; $\mathrm{PBS}=$ phosphate-buffered saline; TNF- $\alpha=$ tumor necrosis factor alpha. 
CD4 ${ }^{+} \mathrm{T}$ cells. The use of tumor cells in such an approach should also provide a broad spectrum of presented tumorassociated antigens, resulting in a broader repertoire of elicited T-cell responses.

We aimed to apply this knowledge to breast carcinoma, a tumor known to be relatively nonimmunogenic. This reputed nonimmunogenicity may originate from the inhibitory effects of breast cancer on DC growth and DC differentiation, which depend on the secretion of cytokines such as IL-6, monocyte colony-stimulating factor and vascular endothelial growth factor [22-25]. Therefore, even though our earlier work in melanoma and prostate carcinoma demonstrated the validity of loading DCs with killed tumor cells to elicit specific T-cell immunity, this approach needed to be tested in a setting of breast cancer. Indeed, each type of tumor represents its own entity; for example, different tissue origins render extrapolations from one tumor to another difficult, necessitating separate analysis.

Herein we show that DCs can capture killed breast cancer cells and can subsequently activate CD4 $+T$ cells as well as $\mathrm{CD}^{+} \mathrm{T}$ cells. This represents a novel approach for development of DC-based vaccination protocols in breast cancer and for the identification of shared breast cancer antigens.

\section{Materials and methods Media and reagents}

The complete culture medium was RPMI 1640, 1\% Lglutamine, $1 \%$ penicillin/streptomycin, $50 \mu \mathrm{M}$ 2-mercaptoethanol, $1 \%$ sodium pyruvate, $1 \%$ essential amino acids, and heat-inactivated 10\% FCS (Life Technologies, Grand Island, NY, USA). For T-cell cultures, FCS was replaced by 10\% human serum AB (Gemini Bio-products, Woodland, CA, USA). Granulocyte-monocyte colony-stimulating factor (Leukine, Immunex, Seattle, WA, USA), soluble CD40 ligand (Immunex), and IL-7 (Immunex or R\&D System, Minneapolis, MN, USA) were used at the respective concentrations of $100 \mathrm{ng} / \mathrm{ml}, 200 \mathrm{ng} / \mathrm{ml}$ and $10 \mathrm{IU} / \mathrm{ml}$. IL-4 (ScheringPlough, Kenilworth, NJ, USA, [kindly provided by S. Narula] or R\&D System) was used at $5 \mathrm{ng} / \mathrm{ml}$, and IL-2 (Genzyme Co., Cambridge, MA, USA) was used at $10 \mathrm{IU} / \mathrm{ml}$. Cycloheximide and the DNA dye 7-aminoactinomycin D were obtained from Sigma (St Louis, MO, USA). Anti-Fas mAb, clone CH11 (Beckman-Coulter, Miami, FL, USA), was used at $1 \mu \mathrm{g} / \mathrm{ml}$. Interferon gamma (IFN- $\gamma$ ) was used at $100 \mathrm{ng} / \mathrm{ml}$ (Actimune, InterMune Pharmaceuticals, MD, USA).

\section{Cell lines}

The MCF-7 and HCC1806 breast cancer cell lines were established by Dr A Gazdar and Dr J Minna at UTSW Medical Center, Dallas and are available from the ATCC (Rockville, MD, USA). The K562 and LnCAP prostate carcinoma cell line were from the ATCC. All cell lines were maintained in culture medium. HCC1806 cells were killed by treatment with anti-Fas $\mathrm{mAb}(\mathrm{CH} 11,1 \mu \mathrm{g} / \mathrm{ml}$ for 7 hours) followed by cycloheximide sensitization $(50 \mu \mathrm{g} / \mathrm{ml})$. MCF- 7 cells were killed by gamma irradiation ( $150 \mathrm{~Gy}$, and then cultured for 48 hours in serum-free medium) followed by tumor necrosis factor alpha (TNF- $\alpha$ ) sensitization ( 24 hours at $100 \mathrm{ng} / \mathrm{ml}$ ).

\section{Monocyte-derived DCs}

Monocyte-derived DCs were generated from Ficoll-separated peripheral blood mononuclear cells of HLA-A201+ healthy volunteers (IRB 097-053). Monocytes were enriched by adherence and were cultured with granulocyte-monocyte colony-stimulating factor and IL-4 (>90\% CD1 $\mathrm{a}^{+}$DCs at day 5). DC maturation was induced by 48 hour culture with soluble CD40 ligand, with monocyte-conditioned media or with the combination of IL-1, IL-6 and TNF- $\alpha$.

\section{T-cell purification}

Purified $\mathrm{CD}^{+}$and $\mathrm{CD} 8^{+} \mathrm{T}$ cells (autologous to the DCs) were obtained by peripheral blood mononuclear cell depletion with CD4 mAb (13B8.2), CD8 mAb (B9.11), CD14 mAb (RM 052), CD16 mAb (3G8), CD19 mAb (J4,119), CD56 mAb (NKH-1), anti-HLA-DR mAb (B8.12.2) and antiglycophorin $A$ mAb (D2.10) (all from Immunotech, Marseille, France), and with goat anti-mouse IgG Dynabeads (Dynal, Lake Success, NY, USA).

\section{Confocal analysis}

Cells were allowed to adhere on polylysine-coated slides (Baxter, Deerfield, IL, USA) for $30 \mathrm{~min}$ at room temperature and the supernatant was then removed. After fixation with 4\% paraformaldehyde in PBS, cells were washed with PBS and mounted. Confocal microscopy was performed using a Leica TCS-NT SP (Leica, Deerfield, IL, USA) equipped with argon, krypton, and helium/neon lasers, and using a spectrophotometer to separate the detection channel of FITC $(510-550 \mathrm{~nm})$ and 7-aminoactinomycin D $(600-660 \mathrm{~nm})$.

\section{T-cell proliferation}

T-cell proliferation was measured by thymidine incorporation after 5 days of culture of tumor-loaded DCs and autologous $T$ cells.

\section{Cytokine production}

The cytokine production in day 6 supernatants was determined by ELISA using kits from Pharmingen (San Diego, CA, USA; IL-4, IL-10 and IFN- $\gamma$ ) according to the manufacturer's suggestions.

\section{Generation of CTLs}

Tumor-loaded DCs were cultured with autologous purified $\mathrm{CD}^{+} \mathrm{T}$ cells or autologous peripheral blood lymphocytes 
(a)

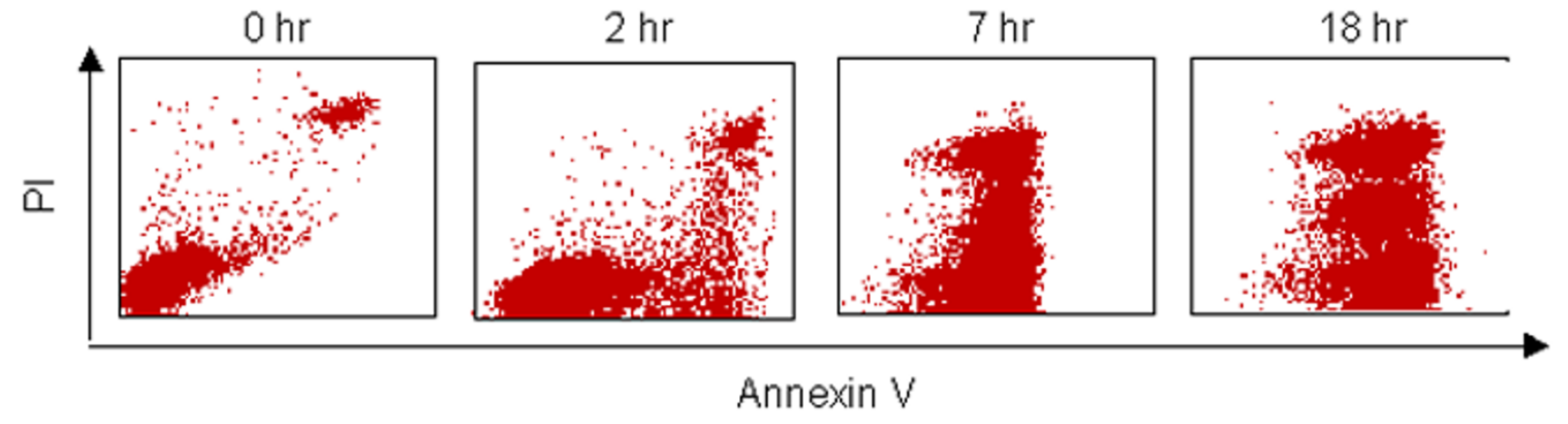

(b)

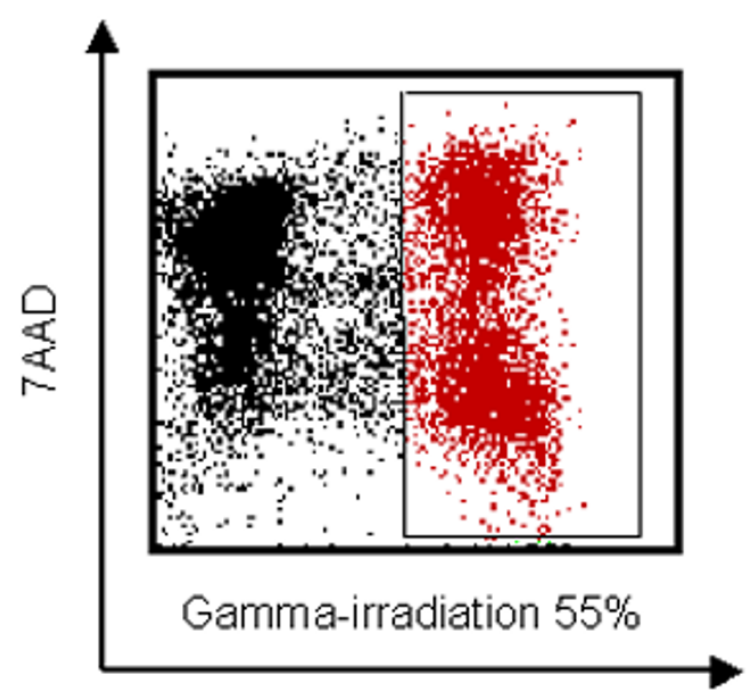

(c)

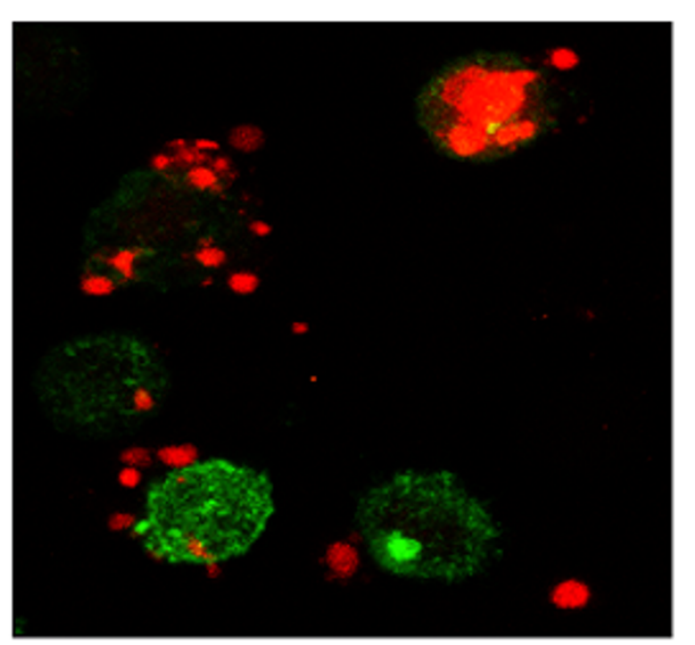

\section{CD1a}

Immature dendritic cells (DCs) capture killed breast cancer cells. (a) HCC1806 cells are treated with treated with cycloheximide $(50 \mathrm{mg} / \mathrm{ml})$ in a sensitization step. After 2 hours at $37^{\circ} \mathrm{C}$, anti-Fas antibody $(\mathrm{CH} 11 ;$ Immunotech) is added at a concentration of $1 \mathrm{mg} / \mathrm{ml}$ and the cells are incubated for the indicated period of time. (b) 7-Aminoactinomycin $D(7 A A D)$-labeled killed breast cancer cells are incubated for 1 hour at $37^{\circ} \mathrm{C}$ with $\mathrm{CD} 1 \mathrm{a}$ labeled immature monocyte derived $D C$ at a $1: 1$ ratio. The capture is determined by flow cytometry (the double-positive CD1a/7AAD represents the DCs that have captured killed breast cancer cells) and confirmed by confocal microscopy (c). Propidium iodide.

(PBL) at $10^{5} \mathrm{DCs}$ and $10^{6} \mathrm{~T}$ cells. Cocultures were restimulated weekly (a total of three stimulations) and supplemented with IL-7 (10 IU/ml in weeks 1 and 2), and IL-2 (10 $\mathrm{IU} / \mathrm{ml}$ in weeks 2 and 3 ). The CTL activity was measured in a standard 4-hour ${ }^{51} \mathrm{Cr}$-release assay, where the ${ }^{51} \mathrm{Cr}$ labeled (NEN Life Science Products Perkin Elmer, Boston, MA, USA) targets were exposed to cultured $T$ cells and lysis was measured after 4 hours of coculture. The percentage of killed cells was calculated using the formula: percentage of release $=100 \times$ (counts per minute [cpm] experiment - cpm spontaneous release)/(cpm maximum release - cpm spontaneous release).

\section{Results}

\section{DCs capture killed breast cancer cells}

MCF-7 and HCC1806 are HLA-A201+ breast cancer cell lines. MCF-7 cells have characteristics of differentiated mammary epithelial cells, express estrogen receptor and are susceptible to TNF. HCC1806 cells are less differentiated and do not express estrogen receptor. HCC1806 cells are sensitive to Fas-induced apoptosis following cycloheximide sensitization (Fig. 1a). MCF-7 cells are Fas resistant but could be killed by a combination of gamma irradiation (150 grays) and serum starvation. Because both HCC1806 and MCF-7 grow as adherent cells and detach 
(a)

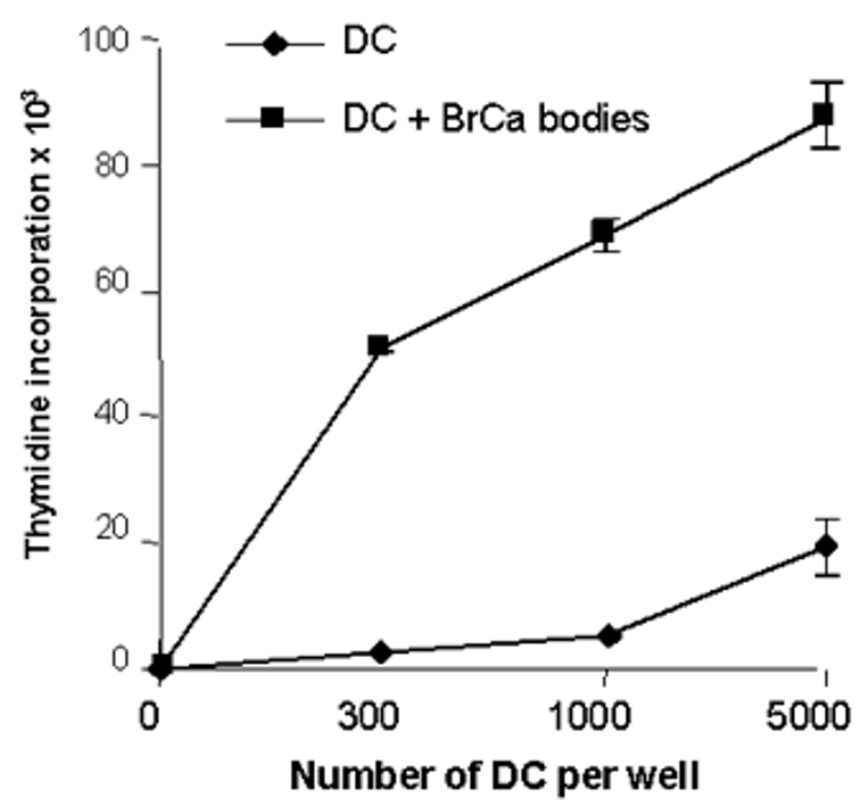

(b)

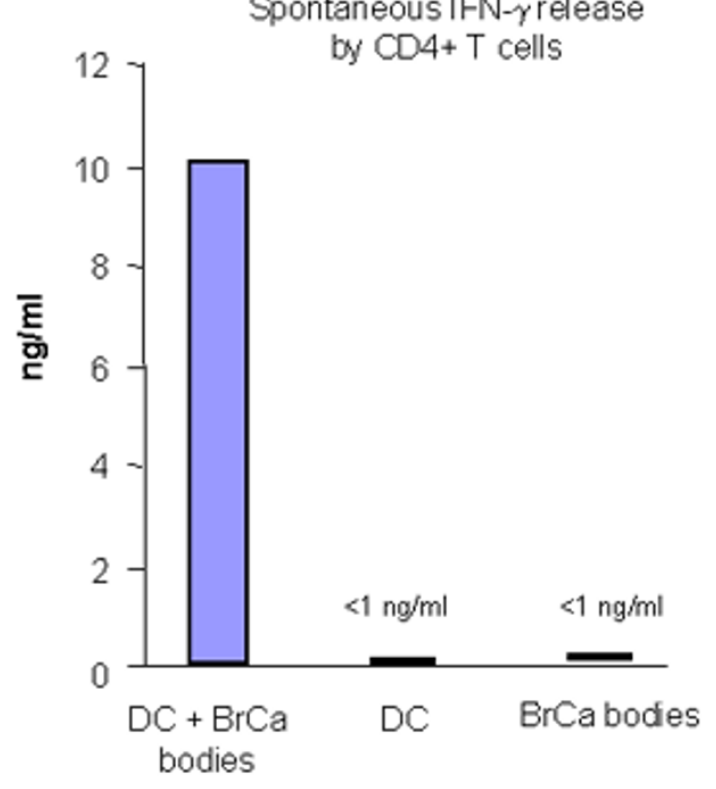

Dendritic cells (DCs) loaded with killed breast cancer ( $\mathrm{BrCa}$ ) cells induce CD4+ ${ }^{+}$-cell proliferation with a strong $\mathrm{T}$ helper type 1 cell polarization. Unloaded DCs and HCC1806-loaded DCs are cultured with purified CD4+ T cells. (a) T-cell proliferation is determined by thymidine incorporation at day 5. No proliferation is detected when $\mathrm{CD} 4^{+} \mathrm{T}$ cells are cultured with killed $\mathrm{BrCa}$ only without DCs (data not shown). (b) Supernatants of DC Tcell cultures are analyzed by ELISA for the levels of interferon gamma (IFN- $\gamma$ ). Results are representative of two experiments.

when dying, the nonadherent fraction can be used as a convenient source of killed cells for DC loading.

Immature monocyte-derived DCs were able to capture killed breast cancer cells after 1 hour of incubation at a ratio of $1: 1$ at $37^{\circ} \mathrm{C}$ (Fig. 1b,1c). Flow cytometry analysis and confocal microscopy, using 7-aminoactinomycin D-labeled killed breast cancer cells and CD1a-labeled immature DCs, show significant phagocytosis. Loaded DCs that were recultured for 48 hours with cytokines survived as well as unloaded cells, and were as efficient in inducing the proliferation of allogeneic naïve T cells (data not shown). This demonstrates that the capture of killed breast cancer cells does not grossly affect DC function.

\section{DCs loaded with killed breast cancer cells induce} proliferation of autologous IFN $-\gamma$, producing CD4 $^{+} \mathbf{T}$ cells We next determined whether DCs that captured killed allogeneic breast tumor cells can present cell-derived antigens to induce $\mathrm{CD}^{+}{ }^{+} \mathrm{T}$-cell proliferation. Immature $\mathrm{DCs}$ were thus loaded with killed breast cancer cells, were induced to mature in 48 hour culture with either CD40 ligand or cytokine cocktail, and were used as stimulators in coculture with autologous CD4 T cells.
CD4 T-cell proliferation was found only in cocultures with tumor-loaded DCs (Fig. 2a) but not in cultures with either unloaded DCs or killed breast cancer cells only (data not shown). The proliferating autologous $\mathrm{CD}^{+} \mathrm{T}$ cells secreted high levels of IFN- $\gamma$ (Fig 2b) and neither IL-4 nor IL-10 could be detected (data not shown).

\section{DCs loaded with killed breast cancer cells induce differentiation of CD8 T cells into CTLs}

We next determined whether DCs loaded with killed breast cancer cells elicit CTLs able to kill the tumor cells used for immunization. Tumor-loaded and matured HLA-A201+ DCs were used to stimulate, at weekly intervals, purified autologous CD8 ${ }^{+} \mathrm{T}$ cells over a 3-week culture period.

As shown in Fig. 3a, loaded DCs induced differentiation of CTLs able to kill HCC1806 cells at $37 \pm 2 \%$ specific lysis. The treatment of targets with IFN- $\gamma$ increases their sensitivity to CTLs with $60 \pm 9 \%$ specific lysis (mean \pm standard error, $n=3$ ). The observed lysis is not due to natural killer cells because K562 cells are not lysed. As expected, T cells cultured with unloaded DCs are unable to kill HCC1806 cells. HLA-A201+ CTLs generated with HCC1806-loaded DCs were unable to kill the HLA-A201+ 
Figure 3

(a)

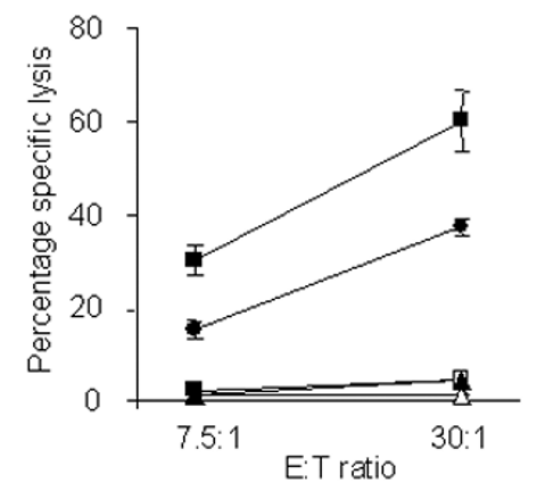

(b)

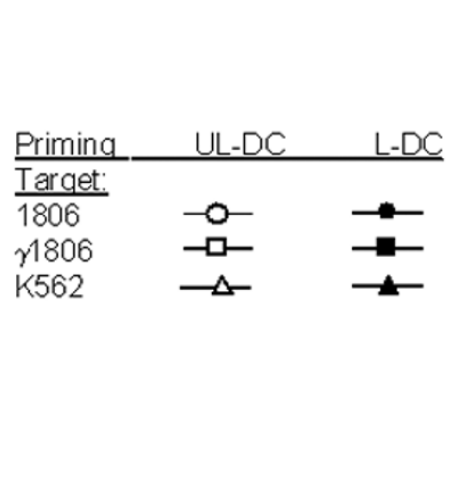

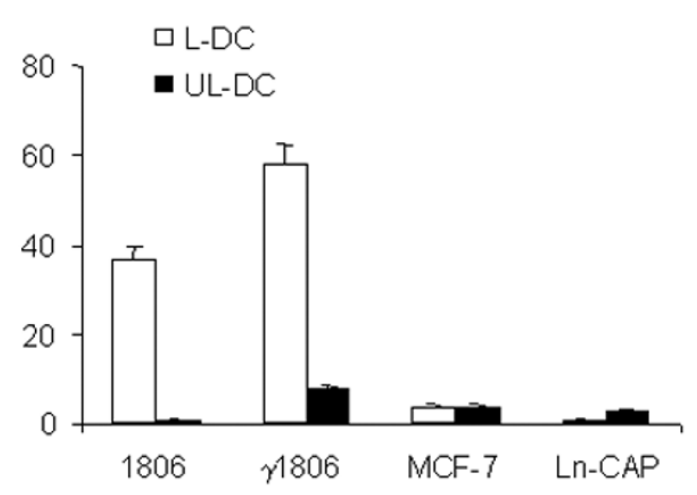

(c)

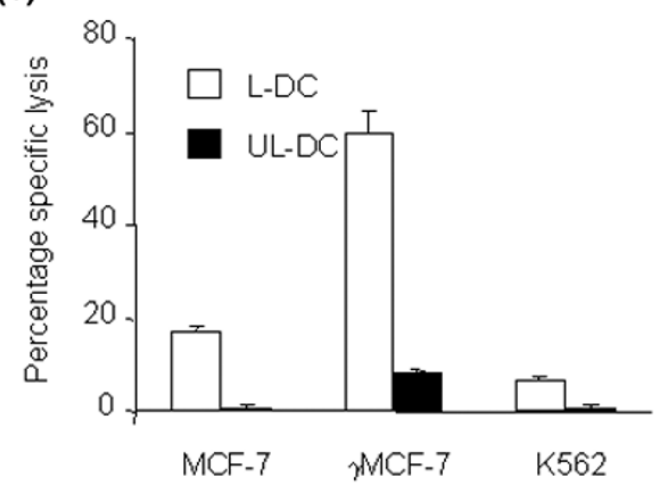

(d)

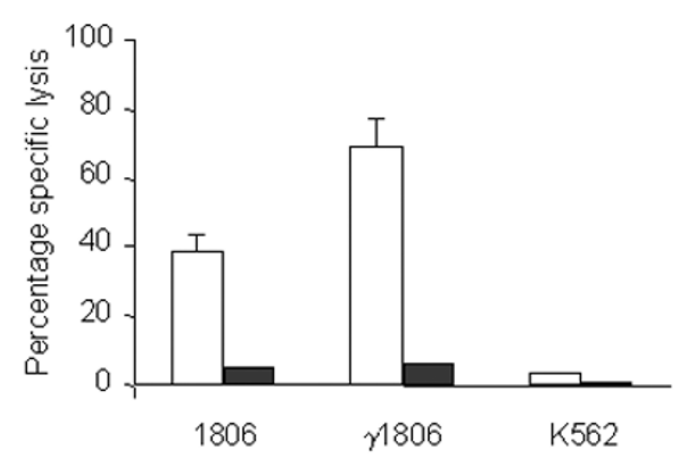

Dendritic cells (DCs) loaded with killed breast cancer cells induce autologous CD8 T-cell differentiation into cytotoxic lymphocytes (CTLs). Purified CD8 ${ }^{+}$T cells are cultured for 3 weeks with unloaded DCs (UL-DC) or with DCs loaded with killed HCC1806 (L-DC). T cells are tested in a 4-hour chromium release assay, using $\mathrm{HCC} 1806$ cells as targets and K562 cells as controls for natural killer activity (mean \pm standard error, $n=3$ ) (a), as well as unrelated HLA-A201+ tumor cell lines, prostate cancer cells (Ln-CAP) and another breast cancer cell (MCF-7) (b). No CTLs are elicited when T cells are cultured with killed breast cancer cells without the DCs (data not shown). In another set of experiments, peripheral blood lymphocytes $\left(C D 4^{+}\right.$and CD8 ${ }^{+}$T cells) are cultured for 3 weeks with UL-DC, or with DCs loaded with killed MCF-7 (c) or with L-DC (d). Results are representative of two experiments.

prostate carcinoma cell line LnCap, suggesting a lack of shared tumor antigens between these two cell lines. However, HCC1806-primed HLA-A201+ CTLs were also unable to kill the HLA-A201+ MCF-7 breast cancer cells.

Because breast cancer cells have been shown to inhibit DC functions as well as CD4 T-cell differentiation, we analyzed CTL differentiation from unseparated PBL. The PBL were cultured with mature DCs loaded with killed breast cancer cells for 3 weeks (three stimulations) without adding supplementary cytokines (IL-7 or IL-2). As shown in Fig. 3 , cultured PBL composed of $80 \%$ CD4 ${ }^{+} \mathrm{T}$ cells are able to kill the breast cancer cells used for the immunization, either MCF-7 cells (Fig. 3c) or HCC1806 cells (Fig. 3d). As already described, IFN- $\gamma$-treated targets were found to be more sensitive to CTLs. DCs loaded with killed breast can- cer cells can thus induce CTLs able to kill the tumor used for immunization.

\section{Discussion}

Given the limited availability of defined breast tumor-associated antigens, the present study was designed to identify conditions permitting the loading of DCs with killed allogenic breast cancer cell lines. This involved a two-pronged strategy that would allow the development of new breast cancer vaccines at two levels. First was the preparation of vaccines that may be used in patients suffering from breast cancer, which would capitalize on the response to 'unknown' shared breast cancer antigens. Then there was the identification of such unknown antigens through cloning of elicited T cells. 
In the present study, we identified clinical-grade conditions that yield killed breast cancer cells, which can be captured by DCs. The captured breast cancer cells were processed by DCs to generate both class I and class II peptides complexes recognized by $\mathrm{CD}^{+} \mathrm{T}$ cells and $\mathrm{CD} 4^{+} \mathrm{T}$ cells, respectively. To our knowledge, this is the first study that demonstrates the generation of breast cancer-specific CTLs, using DCs loaded with killed allogeneic breast cancer cell lines. The major question that arises is the nature of antigens presented by loaded DCs against which the $T$ cells have been primed (i.e. are they breast cancer-specific antigens or alloantigen-specific antigens?).

Our previous studies with both prostate carcinoma and melanoma indicated that a possible generation of allo-specific T cells did not prevent the development of CTLs specific for shared tumor antigens, as identified by the ability of primed CTLs to kill peptide-pulsed T2 cells. Indeed, PSAspecific CTLs were generated when using DCs loaded with prostate carcinoma cells [21], while MART/Tyrosinase/GP-100/MAGE-3-specific CTLs could be elicited culturing $\mathrm{CD}^{+} \mathrm{T}$ cells with $\mathrm{DCs}$ loaded with killed melanoma cells [20].

At variance with these earlier findings in melanoma and prostate carcinoma, here we were unable to establish specificity of elicited CTLs against known tumor antigens such as TERT, focal adhesion kinase-derived peptides or c-erb2. This would suggest that in the case of breast cancer the alloantigen presentation by loaded DCs overshadows the presentation of tumor antigens, and would explain the lack of cross-killing between the two breast cancer cell lines used for experiments. An alternative explanation is that these antigens are not immunodominant antigens presented by loaded DCs. Indeed, owing to their unique biological characteristics, the two breast cancer cell lines that we have used might provide very different immunodominant tumor-associated antigen epitopes. MCF-7 cells are highly differentiated mammary epithelial cells and express estrogen receptor, while HCC1806 cells are less differentiated and do not express estrogen receptor.

Further studies are thus needed to determine the potential therapeutic value of DCs loaded with killed allogeneic breast cancer cells. The demonstration here that DCs loaded with killed allogeneic breast cancer cells can induce CTL differentiation provides a novel approach for identification of shared breast cancer antigens through T-cell cloning.

\section{Conclusion}

Loading DCs with killed breast cancer cells may be considered a novel approach to breast cancer immunotherapy and to identification of shared breast cancer antigens.

\section{Competing interests}

None declared.

\section{Acknowledgements}

The authors thank Dr Esteban Celis for the generous gift of focal adhesion kinase and c-erb-2-derived peptides, and they thank Dr Pascale

Chomarat for help in experiments with induction of cell death. This work was supported by National Institutes of Health grant CA89440 to AKP.

\section{References}

1. Gnjatic S, Jager E, Chen W, Altorki NK, Matsuo M, Lee SY, Chen Q, Nagata Y, Atanackovic D, Chen YT, Ritter G, Cebon J, Knuth A, Old LJ: CD8(+) T cell responses against a dominant cryptic HLA-A2 epitope after NY-ESO-1 peptide immunization of cancer patients. Proc Natl Acad Sci USA 2002, 99:11813-11818.

2. Knuth A, Wolfel T, Klehmann E, Boon T, Meyer zum Buschenfelde $\mathrm{KH}$ : Cytolytic T-cell clones against an autologous human melanoma: specificity study and definition of three antigens by immunoselection. Proc Natl Acad Sci USA 1989, 86:2804-2808.

3. Rosenberg SA: Cancer vaccines based on the identification of genes encoding cancer regression antigens. Immunol Today 1997, 18:175-182.

4. Rosenberg SA: Principles of cancer management: biologic therapy. In Cancer: Principles \& Practice of Oncology 5th edition. Edited by: DeVita VT Jr, Hellman S, Rosenberg SA. Philadelphia, PA: Lippincott-Raven Publishers; 1997:346-373.

5. van der Bruggen $P$, Traversari $C$, Chomez $P$, Lurquin $C$, De Plaen $E$, Van den Eynde B, Knuth A, Boon T: A gene encoding an antigen recognized by cytolytic $T$ lymphocytes on a human melanoma. Science 1991, 254:1643-1647.

6. Yee C, Thompson JA, Byrd D, Riddell SR, Roche P, Celis E, Greenberg PD: Adoptive T cell therapy using antigen-specific $\mathrm{CD}^{+} \mathrm{T}$ cell clones for the treatment of patients with metastatic melanoma: in vivo persistence, migration, and antitumor effect of transferred T cells. Proc Natl Acad Sci USA 2002, 99:16168-16173.

7. Caux C, Dezutter-Dambuyant C, Schmitt D, Banchereau J: GMCSF and TNF-alpha cooperate in the generation of dendritic Langerhans cells. Nature 1992, 360:258-261.

8. Romani N, Gruner S, Brang D, Kampgen E, Lenz A, Trockenbacher B, Konwalinka G, Fritsch PO, Steinman RM, Schuler G: Proliferating dendritic cell progenitors in human blood. J Exp Med 1994, 180:83-93.

9. Sallusto $F$, Lanzavecchia A: Efficient presentation of soluble antigen by cultured human dendritic cells is maintained by granulocyte/macrophage colony-stimulating factor plus interleukin 4 and downregulated by tumor necrosis factor alpha. $J$ Exp Med 1994, 179:1109-1118.

10. Dallal RM, Lotze MT: The dendritic cell and human cance vaccines. Curr Opin Immunol 2000, 12:583-588.

11. Morse MA, Lyerly HK: Immunotherapy of cancer using dendritic cells. Cytokines Cell Mol Ther 1998, 4:35-44.

12. Nair SK, Heiser A, Boczkowski D, Majumdar A, Naoe M, Lebkowsk JS, Vieweg J, Gilboa E: Induction of cytotoxic T cell responses and tumor immunity against unrelated tumors using telomerase reverse transcriptase RNA transfected dendritic cells. Nat Med 2000, 6:1011-1017.

13. Nair SK, Morse M, Boczkowski D, Cumming RI, Vasovic L, Gilboa $\mathrm{E}$, Lyerly HK: Induction of tumor-specific cytotoxic T lymphocytes in cancer patients by autologous tumor RNA-transfected dendritic cells. Ann Surg 2002, 235:540-549.

14. Ribas A, Butterfield LH, Glaspy JA, Economou JS: Cancer immunotherapy using gene-modified dendritic cells. Curr Gene Ther 2002, 2:57-78.

15. Tjoa BA, Murphy GP: Development of dendritic-cell based prostate cancer vaccine. Immunol Lett 2000, 74:87-93.

16. Boczkowski D, Nair SK, Snyder D, Gilboa E: Dendritic cells pulsed with RNA are potent antigen-presenting cells in vitro and in vivo. J Exp Med 1996, 184:465-472.

17. Celluzzi CM, Mayordomo Jl, Storkus WJ, Lotze MT, Falo LD Jr: Peptide-pulsed dendritic cells induce antigen-specific CTL- 
mediated protective tumor immunity. J Exp Med 1996, 183:283-287.

18. Flamand V, Sornasse T, Thielemans K, Demanet C, Bakkus M, Bazin H, Tielemans F, Leo O, Urbain J, Moser M: Murine dendritic cells pulsed in vitro with tumor antigen induce tumor resistance in vivo. Eur $\mathrm{J}$ Immunol 1994, 24:605-610.

19. Zitvogel L, Mayordomo Jl, Tjandrawan T, DeLeo AB, Clarke MR, Lotze MT, Storkus WJ: Therapy of murine tumors with tumor peptide-pulsed dendritic cells: dependence on T cells, B7 costimulation, and Thelper cell 1-associated cytokines. J Exp Med 1996, 183:87-97.

20. Berard F, Blanco $P$, Davoust J, Neidhart-Berard EM, Nouri-Shirazi $M$, Taquet N, Rimoldi D, Cerottini JC, Banchereau J, Palucka AK: Cross-priming of naive CD8 T cells against melanoma antigens using dendritic cells loaded with killed allogeneic melanoma cells. J Exp Med 2000, 192:1535-1544.

21. Nouri-Shirazi M, Banchereau J, Bell D, Burkeholder S, Kraus ET, Davoust J, Palucka KA: Dendritic cells capture killed tumor cells and present their antigens to elicit tumor-specific immune responses. J Immunol 2000, 165:3797-3803.

22. Chomarat $P$, Banchereau J, Davoust J, Palucka AK: IL-6 switches the differentiation of monocytes from dendritic cells to macrophages. Nat Immuno/ 2000, 1:510-514.

23. Gabrilovich DI, Chen HL, Girgis KR, Cunningham HT, Meny GM, Nadaf S, Kavanaugh D, Carbone DP: Production of vascular endothelial growth factor by human tumors inhibits the functional maturation of dendritic cells. Nat Med 1996, 2:1096-1103.

24. Ramakrishnan S, Xu FJ, Brandt SJ, Niedel JE, Bast RC Jr, Brown EL: Constitutive production of macrophage colony-stimulating factor by human ovarian and breast cancer cell lines. $J$ Clin Invest 1989, 83:921-926.

25. Tang R, Beuvon F, Ojeda M, Mosseri V, Pouillart P, Scholl S: M$\mathrm{CSF}$ (monocyte colony stimulating factor) and M-CSF receptor expression by breast tumour cells: M-CSF mediated recruitment of tumour infiltrating monocytes? J Cell Biochem 1992, 50:350-356. 